\title{
Swiss reject GM trial to protect organics
}

[MUNICH] Switzerland's office for environment, forestry and agriculture (BUWAL) has rejected an application from AgrEvo, a German plant biotechnology company, to conduct field trials of its genetically modified (GM) herbicide-resistant 'T25' maize.

BUWAL officials say the site chosen by AgrEvo for its experiments was close to organic farms, and that cross-pollination leading to the contamination of organic crops could not be ruled out.

But the company says it is "mystified and upset" by the decision, and claims that it was made on "political" grounds. Less than a year ago a Swiss referendum rejected an initiative to ban such field trials by a two-thirds majority (see Nature 393, 507; 1998),

The application was one of the first two requests for field-trial licences since the early 1990s. The second, from the Swiss Institute, for field trials on a GM disease-resistant potato, was also rejected this month because of what were considered to be inadequate risk-assessment data. Technical data on the transgene were insufficient, said BUWAL, and the potato carried a marker gene for resistance to an antibiotic used in medicine.

In the case of the AgrEvo trials - to test characteristics of the resistance of T25 maize to the herbicide glufosinate - BUWAL says that the risk of contaminating organic crops is unacceptable. It argues that the application, initially made in 1997, did not include plans for monitoring potential gene flow to soil organisms or neighbouring plants.

"Swiss agriculture lives on the fact that its products are pure and natural," says BUWAL director Philippe Roch.

Wulff Hansen, a spokesman for the chemical company Plüss-Staufer, which represents AgrEvo in Switzerland, says the decision came out of the blue, as the company had already discussed cross-pollination and monitoring with BUWAL.

It had agreed, for example, to prevent the production of pollen by cutting the crop before it flowered. The nearest field used for organic farming was 300 metres away, says Hansen, and did not grow maize, the only type of crop where cross-pollination could occur. The company had also offered to undertake any monitoring activities BUWAL considered necessary. AgrEvo has until early May to decide whether to appeal.

Georg Karlaganis, head of BUWAL's biotechnology division, says the office is keen "to set a high standard". He says that the grounds for rejecting the AgrEvo patent are anticipated changes in a new European Union (EU) directive on the deliberate release of GM organisms. Though Switzerland is not a member of the European Union, its own rules governing the uses of genetic engineering are broadly similar to EU rules.
Proposed changes to the EU directive include a seven-year monitoring period for commercially grown crops. But regulations for field trials will not change substantially under the proposal, and licences, with or without monitoring requirements, will continue to be issued on a case-by-case basis, according to individual risk assessments.

Switzerland is revising its own rules, found in various federal laws, as part of the 'Gen-Lex motion'. This is intended to coordinate the laws relating to genetic engineering and to fill any gaps. It was initiated last year to take some of the heat out of debates leading up to the referendum on genetic engineering (see Nature391, 312; 1998).

AgrEvo management fear that BUWAL will not issue any licences before parliament has approved the Gen-Lex motion, expected at the end of the year, for fear of setting a precedent. But Karlaganis says that BUWAL is not fundamentally against GM crops.

InterNutrition, a group representing the major Swiss food companies, says that it "regrets" the rejection of the two applications and that the move will harm the reputation of Swiss plant biotechnology research.

Isabel Meister, a biotechnology expert for Greenpeace International, sees the rejections as "a step in the right direction". Switzerland is one of the first countries to apply the 'precautionary principle', she says.

Alison Abbott

\section{US processor rejects maize that EU won't take}

[WASHINGTON] The third largest maize (corn) processor in the United States has refused to accept genetically modified (GM) maize that has not been approved for import by the European Union (EU).

In a letter earlier this month to grain elevators, A. E. Staley Manufacturing Co. of Decatur, llinois, said that its plants would not accept GM maize hybrids that have not been approved by the EU. Such hybrids account for about 17 per cent of all GM maize being grown in the United States this year: about 7 per cent of the total US maize crop of some 80 million acres.

Farmers' and processors' trade associations say that the percentage of the crop affected is small and that Staley's move simply reflects a policy adopted by the industry a year ago.

Opponents of GM food see the Staley letter as evidence that public wariness of GM foods in Europe is beginning to force concessions, even as EU and US officials enter what are expected to be rancorous negotiations over labelling (see Nature 398, 641; 1999).

The Corn Refiners Association (CRA) says that customers have asked for EU-unapproved varieties not to be used at facilities where maize is processed for

\begin{tabular}{lll}
\hline How GM varieties are sweeping US cornfields \\
\hline Year & $\begin{array}{l}\text { Number of varieties of } \\
\text { transgenic maize (corn) } \\
\text { planted in the US }\end{array}$ & $\begin{array}{l}\text { Percentage of US } \\
\text { maize acreage }\end{array}$ \\
\cline { 1 - 2 } & one & 0.75 per cent \\
\hline 1996 & seven & 9 per cent \\
\hline 1997 & eleven & 25 per cent \\
\hline 1998 & eleven** & 39 per cent \\
\hline $1999^{*}$ & **Seven are unapproved by EU \\
\hline${ }^{*}$ Numbers for 1999 are estimates & \\
\hline
\end{tabular}

Source: Corn Refiners Association

export. Consequently, it says, its members have asked grain merchants to help farmers avoid delivering EUunapproved maize to refiners or export elevators.

Officials from Cargill Inc. and Archer Daniels Midland (ADM), the two largest US maize processors, said that they were already implementing the CRA policy. Martin Andreas, a senior vice president at ADM, says the company is asking farmers to channel unapproved crops directly to the domestic feed business. "With the cooperation of the seed companies and the farmers and the processors working together this problem can be handled," he says.

Phil Bereano, a professor of technology and public policy at the University of Washington in Seattle, argues that the processors are responding to "plain old simple capitalist supply and demand economics. What has been created is a very substantial market [for nonGM foods] with a sharp border around it. Unfortunately, only European consumers will benefit."

A spokesman for the National Corn Growers Association says that the move should not be construed as a victory for anti-GM food activists. "If anything [the processors position] is a victory for farmers," says Kevin Aandahl. "[t shows] we're responsive to customer needs while we're working through the cultural and trade issues. If anything it's an admission that we're all in this together."

The three affected varieties of GM maize are Monsanto's Roundup Ready, engineered for herbicide resistance; and two $B t$ varieties, engineered to produce a toxin made by a soil bacterium: Monsanto's Bt Xtra (formerly made by DeKalb); and AgrEvo's StarLink. The three, occurring alone or in combination in seven seed products, are expected to be planted on about 5.2 million acres in 1999. 